\title{
REQUIRED TREATMENT INDEX (RTI) PADA PASIEN DEWASA DI KLINIK DOKTER GIGI TJANG RIYANTO CAHYADI KOTA BOGOR
}

\author{
Dhini Ramdiani $^{1}$, Ita Yulita ${ }^{2}$, Bimo G. Sasongko ${ }^{2}$, Tedi Purnama ${ }^{2}$ \\ ${ }^{1}$ Klinik Dokter Gigi Tjang Riyanto Bogor, Indonesia \\ ${ }^{2}$ Jurusan Keperawatan Gigi, Politeknik Kesehatan Kemenkes Jakarta I, Indonesia \\ Info Artikel Abstrak \\ Genesis Naskah: \\ Submitted : 11 Agustus 2020 \\ Revised : 19 Agustus 2020 \\ Accepted : 25 Agustus 2020 \\ Kata Kunci: \\ Required Treatment Index \\ Latar Belakang: Karies gigi merupakan masalah kesehatan gigi dan mulut yang sering dialami \\ oleh hampir seluruh masyarakat di Indonesia. Prevalensi karies gigi kelompok umur usia 35-44 \\ tahun sebesar 92,2\% dengan indeks DMF-T sebesar 6,9. Required Treatment Index (RTI) \\ merupakan angka persentase dari jumlah gigi tetap yang karies terhadap angka DMF-T. RTI \\ menggambarkan besarnya kerusakan yang belum ditangani dan memerlukan penumpatan. \\ Tujuan: Tujuan penelitian ini adalah untuk mengetahui gambaran Required Treatment Index \\ (RTI) pada pasien dewasa di Klinik Gigi Dokter Gigi Tjang Riyanto Cahyadi Kota Bogor pada \\ Bulan Januari 2020. Metode: Penelitian ini menggunakan metode deskriptif dengan sampel \\ penelitian menggunakan teknik purposive sampling sebanyak 35 responden. Data yang \\ digunakan yaitu data sekunder yang diambil dari rekam medis pasien. Hasil: Dari hasil \\ penelitian diperoleh pasien dewasa Klinik Gigi Dokter Gigi Tjang Riyanto Cahyadi memiliki \\ angka pengalaman karies sebesar 10,4. Perhitungan RTI diperoleh 32,4\% termasuk kriteria baik \\ dengan responden yang mempunyai RTI kriteria baik sebanyak 27 orang $(77,1 \%)$ dan RTI \\ kriteria kurang 8 orang $(22,9 \%)$. kelompok umur 36-45 tahun memiliki skor RTI lebih baik dari \\ kelompok umur 26-35 tahun, pasien laki-laki memiliki skor RTI lebih baik dari perempuan. \\ Kesimpulan: Sebagian besar pasien dewasa di Klinik Gigi Dokter Gigi Tjang Riyanto Cahyadi \\ memiliki skor DMF-T dengan kriteria tinggi dan persentase Required Treatment Index dengan \\ kriteria baik.
}

\section{REQUIRED TREATMENT INDEX (RTI) ADULT PATIENTS AT THE TJANG RIYANTO CAHYADI DENTAL CLINIC BOGOR CITY}

\begin{abstract}
Keywords:
Required Treatment Index
\end{abstract}

\begin{abstract}
Background: Dental caries is a dental and oral health problem that is often experienced by almost all people in Indonesia. The prevalence of dental caries in the age group 35-44 years was 92.2\% with a DMF-T index of 6.9. The Required Treatment Index (RTI) is the percentage number of the number of carious permanent teeth against the DMF-T rate and describes the magnitude of tooth decay that has not been treated and requires filling. Objective: The purpose of this study was to determine the Required Treatment Index (RTI) description of adult patients at the Tjang Riyanto Cahyadi Dental Clinic in Bogor City in January 2020. Methods: This study used a descriptive method with a sample of the study using a purposive sampling technique of 35 respondents. The data used are secondary data taken from the patient's medical record. Results: The results showed that Tjang Riyanto Cahyadi Dental Clinic adult patients had caries experience scores of 10.4. The RTI calculation was obtained $32.4 \%$ including good criteria with respondents who had good RTI criteria were 27 people (77.1\%) and RTI criteria were less than 8 people (22.9\%). age group 36-45 years had better RTI scores than age group 26-35 years, male patients had better RTI scores than girls. Conclusion: Most adult patients at Tjang Riyanto Cahyadi Dental Clinic have DMF-T score with high criteria and the percentage of Required Treatment Index with good criteria.
\end{abstract}

\section{Korespondensi Penulis: \\ Tedi Purnama}

Jl. Wijaya Kusuma No. 47-48 Cilandak Jakarta Selatan

email: purnamatedy23@gmail.com

(C) Jurusan Keperawatan Gigi Poltekkes Kemenkes Jakarta I Jl. Wijaya Kusuma No. 47-48 Cilandak Jakarta Selatan, Indonesia email: jdht@poltekkesjakarta1.ac.id 


\section{Pendahuluan}

Masalah kesehatan gigi yang paling menonjol di Indonesia adalah masalah kehilangan gigi akibat karies gigi. Penyakit karies gigi banyak dialami oleh 90\% masyarakat Indonesia (Notohartojo, 2011). Di seluruh dunia, karies berkontribusi 15 kali lebih tinggi sebagai beban penyakit Disability Adjusted Life Year (DALY) dibandingkan dengan penyakit periodontal (Kemenkes RI, 2012). Bahkan Purnama dkk (2019) menyatakan bahwa kesehatan gigi merupakan bagian intergral dari kesehatan secara keseluruhan yang dapat mempengaruhi kualitas hidup.

Karies gigi merupakan suatu proses demineralisasi struktur jaringan keras gigi seperti dentin dan enamel. Karies gigi atau gigi berlubang merupakan masalah kesehatan gigi dan mulut yang sering dialami oleh hampir seluruh masyarakat di Indonesia (Sosiawan, dkk, 2016). Survei Nasional Riskesdas 2018 melaporkan sebesar 92,2\% penduduk Indonesia usia 35-44 tahun mengalami masalah kesehatan gigi; dengan indeks DMF-T sebesar 6,9 artinya rata-rata jumlah kerusakan gigi sebesar 6 sampai 7 gigi setiap orang (Riskesdas, 2018).

Menurut Tarigan (2013) karies gigi merupakan penyakit jaringan gigi yang ditandai dengan kerusakan jaringan, dimulai dari permukaan gigi meluas ke arah pulpa. Karies gigi dapat dialami oleh setiap orang dan dapat timbul pada satu permukaan atau lebih, serta dapat meluas ke bagian yang lebih dalam dari gigi, misalnya dari email ke dentin atau ke pulpa.

Usia dan jenis kelamin merupakan faktor yang dapat mempengaruhi angka kejadian karies gigi. Beberapa penelitian mengungkapkan bahwa prevalensi karies gigi pada wanita $(59,1 \%)$ lebih tinggi daripada laki-laki (40,9\%). Penelitian lain menunjukkan perbedaan yang lebih besar antara wanita $(65,5 \%)$ dan laki-laki $(34,5 \%)$ yang berarti angka kejadian karies gigi dapat dipengaruhi oleh usia, di mana semakin bertambahnya usia, maka angka kejadian karies akan meningkat (Sosiawan, dkk, 2016). Perawatan yang dapat dilakukan pada karies salah satunya melalui perawatan restorasi. Restorasi merupakan perawatan untuk mengembalikan struktur anatomi dan fungsi gigi yang

(C) Jurusan Keperawatan Gigi Poltekkes Kemenkes Jakarta I Jl. Wijaya Kusuma No. 47-48 Cilandak Jakarta Selatan, Indonesia email: jdht@poltekkesjakarta1.ac.id disebabkan fraktur, atrisi, abrasi, erosi dan karies (Putong, dkk, 2013).

Required Treatment Index (RTI) merupakan angka persentase dari jumlah gigi tetap yang karies terhadap angka DMF-T. RTI menggambarkan besarnya kerusakan yang belum ditangani dan memerlukan penumpatan/pencabutan (Pratiwi, dkk, 2010). Hasil Riset Kesehatan Dasar 2018 menunjukkan kemampuan dan kemauan penduduk Indonesia untuk memeriksakan gigi atau merawat giginya masih rendah. Persentase nasional kebutuhan perawatan pada kelompok usia 35-44 tahun sebesar $79,9 \%$ dan proporsi tindakan untuk mengatasi masalah gigi berupa penambalan gigi sebesar 4,3\% .

Hasil penelitian Putong, dkk (2013) di Kelurahan Papusungan dengan sampel masyarakat yang berusia 17 tahun ke atas dengan jumlah sampel 106 orang menyatakan bahwa kebutuhan perawatan tertinggi adalah kebutuhan akan restorasi satu permukaan $60,96 \%$, kemudian diikuti restorasi dua permukaan $23,91 \%$ dan yang terendah yaitu restorasi tiga atau lebih permukaan 15,13\%. Penelitian Ganda (2017) pada laki-laki dewasa di lapak pemulung Lebak Bulus menunjukkan persentase RTI sebesar $82 \%$, yang artinya angka tersebut menunjukkan bahwa status kesehatan gigi laki-laki dewasa di lapak pemulung Lebak Bulus masih terlihat buruk.

Klinik Dokter Gigi Tjang Riyanto Cahyadi merupakan salah satu klinik gigi swasta di Kota Bogor yang memberikan pelayanan kedokteran gigi umum dan spesialistik. Dari laporan pelayanan klinik tahun 2019 menunjukkan terdapat 3 (tiga) penyakit gigi dengan jumlah tertinggi yaitu nekrose pulpa, karies dentin dan pulpitis. Penelitian tentang gambaran Required Treatment Index (RTI) pada pasien Klinik Dokter Gigi Tjang Riyanto Cahyadi belum pernah dilakukan.

Berdasarkan latar belakang di atas penulis tertarik untuk melakukan penelitian dengan judul "Gambaran Required Treatment Index (RTI) pada Pasien Dewasa di Klinik Gigi Dokter Gigi Tjang Riyanto Cahyadi Kota Bogor Bulan Januari Tahun 2020”

\section{Metode \\ Jenis penelitian ini menggunakan metode penelitian deskriptif yaitu mengetahui gambaran}


Required Treatment Index (RTI) pada pasien dewasa di Klinik Gigi Dokter Gigi Tjang Riyanto Cahyadi Kota Bogor Bulan Januari Tahun 2020. Populasi dalam penelitian ini adalah data seluruh pasien dewasa yang melakukan penambalan gigi di Klinik Gigi Dokter Gigi Tjang Riyanto Cahyadi pada bulan Januari 2020. Teknik pengambilan sampel menggunakan purposive sampling sebanyak 35 responden dengan kriteria inklusi:

a. Pasien yang berkunjung pada bulan Januari 2020

b. Berusia 26-45 tahun

c. Berjenis kelamin laki-laki dan perempuan

d. Pasien yang dijadikan sampel adalah pasien kunjungan pertama.

Penelitian ini menggunakan data sekunder yang diambil dari rekam medis pasien dewasa yang telah melakukan perawatan gigi bulan Januari 2020, kemudian dicatat menggunakan lembar rekapitulasi yang telah ditentukan oleh peneliti. Penelitian ini diolah dan dianalisa dalam program excel dan disajikan dalam bentuk distribusi frekuensi.

\section{Hasil}

Tabel 1. Distribusi frekuensi karakteristik responden

\begin{tabular}{ccc}
\hline Variabel & Jumlah & Persentasi (\%) \\
\hline Jenis Kelamin & & \\
Laki-laki & 19 & 54.3 \\
Perempuan & 16 & 45.7 \\
Usia & & \\
26-35 tahun & 14 & 40.0 \\
36-45 tahun & 21 & 60.0 \\
\hline
\end{tabular}

Tabel 1. Menunjukkan karakteristik responden didapatkan responden didominasi oleh jenis kelamin laiki-laki sebanyak 19 orang (54.3\%) dan berusia 3645 tahun sebanyak 21 orang $(60 \%)$.

Tabel 2. Gambaran Rata-rata Indek DMF-T

\begin{tabular}{ccccc}
\hline \multirow{2}{*}{$\begin{array}{c}\text { Responden } \\
\text { (orang) }\end{array}$} & \multicolumn{3}{c}{ Komponen DMF-T } & Indek \\
\cline { 2 - 4 } & Decay & Missing & Filling & DMF-T \\
\hline 35 & 118 & 63 & 183 & 364 \\
\hline Rata-rata & 3.4 & 1.8 & 5.2 & 10.4 \\
\hline
\end{tabular}

Tabel 2 menunjukkan bahwa dari 35 responden didapatkan skor DMF-T sebesar 364 dan DMF-T

(C) Jurusan Keperawatan Gigi Poltekkes Kemenkes Jakarta I Jl. Wijaya Kusuma No. 47-48 Cilandak Jakarta Selatan, Indonesia email: jdht@poltekkesjakarta1.ac.id rata-rata sebesar 10,4 dengan skor $\mathrm{D}=3.4, \mathrm{M}=1.8$, $\mathrm{F}=5.2$. Hal ini dapat diartikan bahwa setiap orang yang diperiksa memiliki pengalaman karies gigi sebanyak 10 - 11 gigi tiap responden.

Hasil penelitian didapatkan perhitungan Required Treatment Index (RTI) pada pasien dewasa di Klinik Gigi Dokter Gigi Tjang Riyanto Cahyadi dapat digunakan perhitungan dengan rumus sebagai berikut:

$$
R T I=\frac{118}{364} \times 100 \%=32,4 \%
$$

Dari data pada perhitungan diatas dapat diketahui kebutuhan perawatan karies pasien dewasa di Klinik Gigi Dokter Gigi Tjang Riyanto Cahyadi Kota Bogor pada bulan Januari 2020 adalah sebesar $32,4 \%$ termasuk kriteria baik. Kemudian dilakukan pengelompokkan Required Treatment Index berdasarkan kriteria RTI yaitu dapat dilihat pada tabel berikut:

Tabel 3. Distribusi frekuensi Required Treatment Index

\begin{tabular}{ccc}
\hline Skor RTI & Jumlah & Persentasi (\%) \\
\hline Baik $(<50 \%)$ & 28 & 80 \\
Kurang $(\geq 50 \%)$ & 7 & 20 \\
\hline Jumlah & 35 & 100 \\
\hline
\end{tabular}

Tabel 3 menunjukkan bahwa responden yang mempunyai RTI kriteria baik sebanyak 28 orang (80\%) dan responden yang mempunyai RTI kriteria kurang sebanyak 7 orang $(20 \%)$.

Tabel 4. Distribusi frekuensi Required Treatment Index berdasarkan umur

\begin{tabular}{cccc}
\hline \multirow{2}{*}{ Skor RTI } & \multicolumn{2}{c}{ Umur (tahun) } & \multirow{2}{*}{ Jumlah } \\
\cline { 2 - 3 } & $\mathbf{2 6 - 3 5}$ & $\mathbf{3 6 - 4 5}$ & \\
\hline Baik $(<50 \%)$ & 11 & 16 & 27 \\
Kurang $(\geq 50 \%)$ & 3 & 5 & 8 \\
\hline Jumlah & 14 & 21 & 35 \\
\hline
\end{tabular}

Tabel 4 menunjukkan bahwa skor RTI dengan kriteria baik terdapat pada 11 orang responden berumur 26-35 tahun, sedangkan pada kelompok umur 36-45 tahun terdapat 16 orang responden

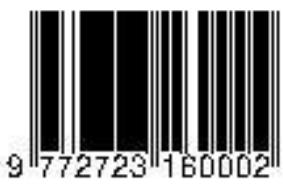


memiliki skor RTI dengan kriteria baik. Untuk skor RTI dengan kriteria kurang, terdapat pada 3 orang responden dalam kelompok umur 26-35 tahun dan 5 orang pada kelompok umur 36-45 tahun.

Tabel 5. Distribusi frekuensi Required Treatment Index berdasarkan jenis kelamin

\begin{tabular}{cccc}
\hline \multirow{2}{*}{ Skor RTI } & \multicolumn{2}{c}{ Jenis Kelamin } & Jumlah \\
\cline { 2 - 4 } & Laki-laki & Perempuan & \\
\hline Baik $(<50 \%)$ & 15 & 13 & 28 \\
Kurang $(\geq 50 \%)$ & 4 & 3 & 7 \\
\hline Jumlah & 19 & 16 & 35 \\
\hline
\end{tabular}

Tabel 5 menunjukkan bahwa responden laki-laki yang memiliki skor RTI dengan kriteria baik sebanyak 15 orang dan responden perempuan sebanyak 13 orang, sedangkan responden laki-laki yang memiliki skor RTI dengan kriteria kurang sebanyak 4 orang dan responden perempuan sebanyak 3 orang.

\section{Pembahasan}

Hasil penelitian diperoleh angka pengalaman karies gigi rata-rata Decay sebesar 3,4, Missing sebesar 1,8 dan Filling sebesar 5,2 sehingga skor rata-rata DMF-T sebesar 10,4 yang masuk dalam kriteria sangat tinggi. Bila dibandingkan dengan hasil penelitian Tjahja dan Ghani (2010) pada pengunjung Puskesmas yang mendapatkan skor DMF-T >6, pasien yang berkunjung ke Klinik Gigi Dokter Gigi Tjang Riyanto Cahyadi memiliki skor DMF-T ratarata yang jauh lebih tinggi.

Tingginya karies gigi pasien dewasa di Klinik Gigi Dokter Gigi Tjang Riyanto Cahyadi dimungkinkan karena responden mayoritas berumur 36-45 tahun, didukung pendapat Tarigan (2013) menyatakan keadaan atau kondisi gigi kelompok umur tua lebih buruk dibandingkan kelompok umur muda, artinya semakin bertambah umur seseorang berisiko terkena karies. Notohardjo dkk (2011) juga menyatakan bahwa karies gigi dipengaruhi oleh faktor umur. Semakin umur tua, semakin mudah terkena karies gigi, begitu juga sebaliknya semakin muda jarang terkena karies. Sosiawan dkk (2016) mengungkapkan bahwa karies gigi adalah salah satu penyakit yang terjadi di rongga mulut yang salah satu

(C) Jurusan Keperawatan Gigi Poltekkes Kemenkes Jakarta I J1. Wijaya Kusuma No. 47-48 Cilandak Jakarta Selatan, Indonesia email: jdht@poltekkesjakarta1.ac.id penyebabnya adalah adanya endapan plak yang mudah melekat pada gigi. Penyakit ini dapat menyerang siapa saja dengan tidak mengenal perbedaan status, agama, bangsa, jenis kelamin maupun umur.

Hasil perhitungan Required Treatment Index (RTI) didapatkan persentase sebesar 32,4\%, yang artinya sudah berada dalam target pencapaian nasional sebesar $<50 \%$, dengan responden yang mempunyai RTI kriteria baik sebanyak 27 orang $(77,1 \%)$ dan masih ada responden dengan RTI kriteria kurang sebanyak 8 orang $(22,9 \%)$. Hal ini menunjukkan bahwa responden telah melakukan perawatan gigi, terbukti dari tingginya jumlah skor $\mathrm{F}$ (Filling) sebesar 5.2 dibandingkan skor D (Decay) dan M (Missing). Hal ini mungkin disebabkan faktor tingginya sosial ekonomi dan pengetahuan responden tentang perawatan lubang gigi. Sesuai juga dengan pendapat Pratiwi dkk (2010) seseorang yang giginya berlubang akan mengalami rasa sakit yang amat sangat, rasa sakit ini yang kemungkinan akan menimbulkan upaya seseorang untuk tidak mengalaminya lagi sehingga menimbulkan effort atau upaya untuk melakukan pencegahan berupa penambalan gigi.

Hasil gambaran Required Treatment Index (RTI) berdasarkan kelompok umur menunjukkan bahwa jumlah responden dengan persentase RTI kriteria baik lebih banyak bila dibandingkan dengan reponden dengan kriteria kurang baik, baik pada kelompok umur dewasa awal (26-35 tahun) maupun pada kelompok umur dewasa akhir (36-45 tahun). Pada kelompok umur 36-45 tahun didapatkan jumlah responden dengan RTI kriteria baik lebih banyak dibandingkan usia 26-35 tahun. Hal tersebut dikarenakan usia lebih tua lebih cenderung berusaha untuk mendapatkan perawatan gigi dan mulut. Didukung oleh pendapat Herwanda dkk (2016) kebutuhan perawatan dipengaruhi oleh berbagai faktor predisposisi, salah satunya adalah faktor usia. Kelompok usia yang berbeda, memiliki jenis dan jumlah penyakit yang berbeda, artinya semakin tinggi usia seseorang maka semakin besar kebutuhan perawatan gigi yang dibutuhkan. 
Hasil gambaran Required Treatment Index (RTI) berdasarkan jenis kelamin menunjukkan bahwa RTI dengan kriteria baik terdapat pada responden laki-laki dan perempuan dengan jumlah lebih banyak dibandingkan responden dengan RTI kriteria kurang. Jumlah responden laki-laki lebih banyak memiliki RTI kriteria baik dibandingkan perempuan. Hal ini berbeda dengan penelitian Ganda (2017) yang menunjukkan bahwa status kesehatan gigi laki-laki dewasa lebih buruk.

\section{Kesimpulan}

Berdasarkan hasil penelitian, dapat disimpulkan bahwa:

1. Pasien dewasa di Klinik Gigi Dokter Gigi Tjang Riyanto Cahyadi memiliki angka pengalaman karies gigi (DMF-T) kategori sangat tinggi yaitu 10,4 .

2. Pasien dewasa di Klinik Gigi Dokter Gigi Tjang Riyanto Cahyadi memiliki skor Required Treatment Index (RTI) termasuk dalam kriteria baik dengan hasil RTI $<50 \%$

3. Pasien pada kelompok umur 36-45 tahun memiliki skor RTI lebih baik daripada kelompok umur 2635 tahun

4. Pasien laki-laki memiliki skor RTI lebih baik daripada perempuan.

\section{Saran}

Sehubungan dengan hasil penelitian maka dapat disarankan sebagai berikut:

1. Diharapkan bagi pasien untuk menjaga kesehatan gigi dan mulut, sehingga dapat meminimalkan terjadinya masalah gigi dan mulutnya serta pasien yang masih memiliki karies gigi diharapkan untuk dilakukan penambalan supaya pengunyahan tetap baik dan optimal.

2. Diharapkan klinik gigi Dokter Gigi Tjang Riyanto Cahyadi untuk mengadakan program penyuluhan kesehatan gigi secara terprogram khususnya tentang perawatan gigi

3. Disarankan untuk melakukan penelitian selanjutnya mengenai Required Treatment Index pada pasien lansia agar dapat dijadikan perbandingan dengan kelompok dewasa.

\section{Daftar Pustaka}

Ganda R (2017). Gambaran Indeks DMF-T dan Required Treatment Index (RTI) Pada Laki-Laki Dewasa di Lapak Pemulung Rt 014 / Rw 04 Lebak Bulus Tahun 2017. Karya Tulis Ilmiah. Jurusan Keperawatan Gigi Poltekkes Kemenkes Jakarta I.

Herwanda, Liana R, Sari N (2014). Gambaran Kebutuhan Perawatan Gigi Dan Mulut Pada Pasien Di Posyandu Lansia Puskesmas. Cakradonya Dent J. 2014; 6(1):619-677

Kementerian Kesehatan Republik Indonesia (2012). Pedoman Paket Dasar Pelayanan Kesehatan Gigi Dan Mulut di Puskesmas. Direktorat Jenderal Bina Upaya Kesehatan, Jakarta.

Kementerian Kesehatan Republik Indonesia (2018). Riset Kesehatan Dasar. Badan Penelitian dan Pengembangan, Jakarta

Notohartojo TI, Ghani L, (2010). Status Kesehatan Gigi Dan Mulut Ditinjau Dari Faktor Individu Pengunjung Puskesmas DKI Jakarta Tahun 2007. Buletin Penelitelitian Kesehatan: Vol. 38, No. 2, 2010: 52 -66

Notohartojo TI, Made LS, Woro R, Olwin N (2011). Nilai Karies Gigi Pada Karyawan Kawasan Industri Di Pulo Gadung Jakarta. Media Litbang Kesehatan. Volume 21 Nomor 4 Tahun 2011

Pratiwi LN, Basuki H, Soeprapto A (2010). Pengaruh Akses Pelayanan Kesehatan, Performed Treament Index/Pti Requirement Treatment Index/Rti, Terhadap Perilaku Oral Hygiene. Buletin Penelitian Sistem Kesehatan. Vol. 13 No. 2 April 2010: 169-180

Purnama T, Rasipin R, Santoso B. (2019). Pengaruh Pelatihan Tedi's Behavior Change Model pada Guru dan Orang Tua terhadap Keterampilan Menggosok Gigi Anak Prasekolah. Jurnal Quality Kesehatan. 13(2):75-81.

Putong DC, Wowor NS, Vonny, Wicaksono AD (2013). Gambaran Karies Dan Kebutuhan Perawatan Restorasi Pada Masyarakat Di Kelurahan Papusungan Kecamatan Lembeh Selat. Naskah Publikasi. Program Studi Kedokteran Gigi Fakultas Kedokteran Universitas Sam Ratulangi 
Sosiawan A, Heroesoebekti R, Hapsoro A, Santos ML (2016). Gambaran Tingkat Keparahan Karies Gigi Pada Ibu-ibu Usia 36-45 Tahun Dusun Claket Desa Claket Kecamatan Pacet Kabupaten Mojokerto Pada Bulan April 2016. Search Report. Fakultas Kedokteran Gigi.

Tarigan R (2013). Karies Gigi Edisi 2. Jakarta: Penerbit EGC. 